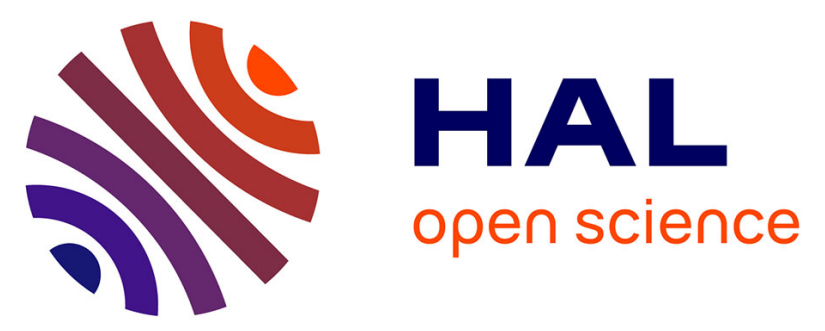

\title{
Clinical and molecular delineation of Tetrasomy 9p syndrome: Report of 12 new cases and literature review
}

Laïla El Khattabi, Sylvie Jaillard, Joris Andrieux, Laurent Pasquier, Laurence

Perrin, Yline Capri, Abdelmadjid Benmansour, Annick Toutain, Pascale

Marcorelles, Catherine Vincent-Delorme, et al.

\section{To cite this version:}

Laïla El Khattabi, Sylvie Jaillard, Joris Andrieux, Laurent Pasquier, Laurence Perrin, et al.. Clinical and molecular delineation of Tetrasomy 9p syndrome: Report of 12 new cases and literature review. American Journal of Medical Genetics Part A, 2015, 167 (6), pp.1252-1261. 10.1002/ajmg.a.36932 . hal-01165441

HAL Id: hal-01165441

https://hal-univ-rennes1.archives-ouvertes.fr/hal-01165441

Submitted on 16 Sep 2015

HAL is a multi-disciplinary open access archive for the deposit and dissemination of scientific research documents, whether they are published or not. The documents may come from teaching and research institutions in France or abroad, or from public or private research centers.
L'archive ouverte pluridisciplinaire HAL, est destinée au dépôt et à la diffusion de documents scientifiques de niveau recherche, publiés ou non, émanant des établissements d'enseignement et de recherche français ou étrangers, des laboratoires publics ou privés. 
El Khattabi et al., 1

Title: Clinical and molecular delineation of Tetrasomy 9p syndrome: report of 12 new cases and literature review

Running title: Delineation of Tetrasomy 9p syndrome

Authors:

Laïla El Khattabi ${ }^{1,2}$, Sylvie Jaillard ${ }^{3}$, Joris Andrieux ${ }^{4}$, Laurent Pasquier ${ }^{5}$, Laurence Perrin ${ }^{6}$, Yline Capri $^{6}$, Abdelmadjid Benmansour ${ }^{7}$, Annick Toutain ${ }^{8}$, Pascale Marcorelles ${ }^{9}$, Catherine VincentDelorme $^{10}$, Hubert Journel ${ }^{11}$, Catherine Henry ${ }^{3}$, Claire De Barace ${ }^{12}$, Louise Devisme ${ }^{13}$, Christèle Dubourg $^{14,15}$, Florence Demurger ${ }^{5}$, Josette Lucas ${ }^{3}$, Marc-Antoine Belaud-Rotureau ${ }^{3,15}$, Jeanne Amiel ${ }^{16}$, Valérie Malan ${ }^{17}$, Marie-Christine De Blois ${ }^{17}$, Loïc De Pontual ${ }^{18}$, Nathalie Le Dû́ ${ }^{2}$, Dominique Germain $^{19}$, Jean-Marc Pinard ${ }^{20}$, Eva Pipiras ${ }^{21}$, Anne-Claude Tabet ${ }^{6}$, Azzedine Aboura ${ }^{6}$, Alain Verloes $^{6,22}$

1. Cochin Institute, INSERM U1016, Paris, France

2. Cytogenetics Department, APHP, Cochin Hospital, Paris Descartes University, Paris, France

3. Cytogenetics and Cell Biology Departement, Rennes University Hospital, Rennes, France

4. Medical Genetics Department, Lille Hospital, Lille, France

5. Medical Genetics Department, Rennes University Hospital, Rennes, France

6. Department of Genetics, APHP-Robert Debré University Hospital, Paris, France

7. Pediatrician, Oran, Algeria

8. Department of Genetics, Tours University Hospital, Tours, France

9. Department of Pathology, CHU Brest, France

10. Department of Genetics, Arras Hospital, Arras, France

11. Department of Medical Genetics, CHBA, Vannes, France

12. Department of Pediatrics, Saint-Brieuc Hospital, Saint-Brieuc, France

13. Department of Anatomy and Cell Pathology, CHRU Lille, France

14. Molecular Genetics Department, Rennes University Hospital, Rennes, France

15. UMR 6290, IGDR, Medical School, Rennes, France

16. Department of Genetics, APHP, Necker-Enfants Malades University Hospital, Paris, France

17. Laboratory of Cytogenetics, APHP, Necker-Enfants Malades Hospital, Paris Descartes University, Paris, France

18. Department of Pediatrics, Jean-Verdier Hospital, APHP, Paris 13 University, Bondy, France

19. Department of Genetics, Raymond Poincaré University Hospital, Garches, France

20. Department of Neuropediatrics, Raymond Poincaré University Hospital, Garches, France

21. Cytogenetics, APHP, Jean-Verdier University Hospital, Bondy; Paris 13, Sorbonne Paris Cité, UFR SMBH, Bobigny, France; Inserm, U676, Paris, France

22. INSERM U676, and Paris VII-Denis Diderot Medical School, Paris, France; 


\section{Page 3 of 20}

El Khattabi et al., 2

\section{Correspondence to:}

Dr Laïla El Khattabi

Laboratoire de Cytogénétique

Hôpital Cochin, AP-HP

53, Avenue de l'Observatoire

75014 Paris

France

Tel: +33158413530

Fax: +33158413531

laila.el-khattabi@cch.aphp.fr 
El Khattabi et al., 3

\begin{abstract}
Tetrasomy $9 \mathrm{p}$ is a generic term describing the presence of a supernumerary chromosome incorporating two copies of the $9 p$ arm. Two varieties exist: isodicentric chromosome $9 p$ (i(9p)), where the two $9 p$ arms are linked by a single centromeric region, and pseudodicentric 9p (idic(9p)), where one active and one inactive centromere are linked together by a proximal segment of $9 \mathrm{q}$ that may incorporate euchromatic material. In living patients, $i(9 p)$ and idic(9p) are usually present in a mosaic state. Fifty four cases, including fetuses, have been reported, of which only two have been molecularly characterized using array-CGH. Tetrasomy $9 \mathrm{p}$ leads to a variable phenotype ranging from multiple congenital anomalies with severe intellectual disability and growth delay to subnormal mental and physical developments. Hypertelorism, dysplastic ears, microretrognathia and bulbous nose are the most common dysmorphic traits. Microcephaly, growth retardation, joint dislocation, scoliosis, cardiac and renal anomalies were reported in several cases. Those physical anomalies are often, but not universally, accompanied by intellectual deficiency. The most recurrent breakpoints, defined by conventional cytogenetics, are 9p10,9q12 and 9q13. We report on twelve new patients with tetrasomy $9 p$ (3 i (9p), 8 idic(9p) and 1 structurally uncharacterized), including the first case of parental germline mosaicism. All rearrangements have been characterized by DNA microarray. Based on our results and a review of the literature, we further delineate the prenatal and postnatal clinical spectrum of this imbalance. Our results show poor genotype-phenotype correlations and underline the need of precise molecular characterization of the supernumerary marker.
\end{abstract}

Keywords: tetrasomy 9p, isochromosome, microarray, mosaicism 
El Khattabi et al., 4

\section{INTRODUCTION}

9p tetrasomy (T9p) is a rare chromosomal imbalance defined by the presence of a supernumerary chromosome, either an isochromosome or an isodicentric chromosome derived from the short arm of chromosome 9. Ghymers described the first patient in 1973 [Ghymers et al., 1973]. Schematically, the two 9p arms can be separated by: a single centromeric region, leading to an isochromosome (i(9)), or by two centromeres, forming either a dicentric (idic(9)) or a pseudodicentric (psu idic(9)) chromosome, when only one of the two centromeres is active. In idic(9), the two 9p arms are linked together either by a segment of the pericentromeric heterochromatin from $9 \mathrm{q}$ or by a wider $9 \mathrm{q}$-derived segment that incorporates heterochromatic and proximal euchromatic material. In liveborns, T9p is almost always observed in a mosaic state.

Fifty four cases have been reported in 40 years [Abe et al., 1977; Andou et al., 1994; Balestrazzi et al., 1983; Calvieri et al., 1988; Cavalcanti et al., 1987; Cazorla Calleja et al., 2003; Chen et al., 2007; Chen et al., 2012; Chen et al., 2014; Coman et al., 2008; Cuoco et al., 1982; de Azevedo Moreira et al., 2003; Deurloo et al., 2004; Dhandha et al., 2002; di Vera et al., 2008; Dutly et al., 1998; Eggermann et al., 1998; Garcia-Cruz et al., 1982; Ghymers et al., 1973; Grass et al., 1993; Hengstschlager et al., 2004; Henriques-Coelho et al., 2005; Jalal et al., 1991; Leichtman et al., 1996; Lloveras et al., 2004; McAuliffe et al., 2005; McDowall et al., 1989; Melaragno et al., 1992; Moedjono et al., 1980; Nakamura-Pereira et al., 2009; Nakamura et al., 1990; Ogino et al., 2007; Orye et al., 1975; Papenhausen et al., 1990; Papoulidis et al., 2012; Park et al., 1995; Peters et al., 1982; Podolsky et al., 2011; Rutten et al., 1974; Schaefer et al., 1991; Shapiro et al., 1985; Shehab et al., 2011; Stumm et al., 1999; Tan et al., 2007; Tang et al., 2004; Tonk 1997; Van Hove et al., 1994; Wisniewski et al., 1978], among which 20 were prenatally diagnosed [Cazorla Calleja et al., 2003; Chen et al., 2007; Chen et al., 2014; Coman et al., 2008; Deurloo et al., 2004; Dhandha et al., 2002; di Vera et al., 2008; Dutly et al., 1998; Eggermann et al., 1998; Grass et al., 1993; Hengstschlager et al., 2004; McDowall et al., 1989; Nakamura-Pereira et al., 2009; Park et al., 1995; Podolsky et al., 2011; Tan et al., 2007; Tang et al., 2004; Van Hove et al., 1994]. T9p leads to a variable phenotype ranging from multiple congenital anomalies with severe intellectual disability and growth delay to subnormal mental and physical developments. Hypertelorism or telecanthus, dysplastic, low-set ears, microretrognathia and bulbous nose are the most common dysmorphic traits. Microcephaly, growth retardation, joint dislocation, scoliosis, cardiac defects and renal anomalies were reported in several cases (Table 1). Those physical anomalies are often, but not universally accompanied by intellectual deficiency. Only two previously reported patients have been studied by microarray technology [Chen et al., 2014; Shehab et al., 2011]. We report here twelve new cases of T9p with different rearrangements, all studied by DNA microarray.

\section{PATIENTS AND METHODS}


El Khattabi et al., 5

\section{Patient 1}

The patient, an eighteen year-old girl, was the only child of non-consanguineous healthy French parents. Ultrasound scan (USS) during the second trimester detected intrauterine growth retardation (IUGR). Delivery occurred at 39 weeks of gestation (WG) by caesarean section because of a fetal distress. At birth, Apgar score was 10/10 at one and five minutes, birth weight (BW) was $1900 \mathrm{~g}$ (-3 SD), birth Length (BL) was $44 \mathrm{~cm}$ (-3 SD) and occipitofrontal circumference (OFC) was $31 \mathrm{~cm}(-3$ SD). Psychomotor development was delayed. She sat unsupported at 12 months, walked unsupported at 24 months and pronounced her first words at 3 years. She was referred to the genetic clinics at the age of 20 months because of growth retardation and macrocephaly. Standard cytogenetic investigations on peripheral blood demonstrated the presence of a de novo mosaic i(9p). She had brachycephaly, prominent forehead, thin nose, short philtrum, low-set ears and microretrognathia (Fig. $1 \mathrm{a}, \mathrm{b})$. In addition to transient strabismus, she had severe myopia (-18 d), mild cataract onset at age 15 , length asymmetry of lower limbs, knee hyperlaxity, Raynaud disease of four limbs with livedo reticularis, and microdontia with abnormal enamel. Several benign pilomatricomas developed since infancy. Some of them required surgical removal. Radiographic survey revealed delayed ossification of pubic rami and multiple wormian bones. Brain MRI showed ventricular dilation and vermis hypoplasia. She first menstruated at age 17. She was able to follow a mainstream vocational schooling, with difficulties. At last examination, aged 18, she was $165 \mathrm{~cm}$ tall (+ $0.3 \mathrm{SD})$ and had an OFC of 57 $\mathrm{cm}(+1.5 \mathrm{SD})$.

\section{Patient 2}

The second patient, a five year-old boy, was the second child of non-consanguineous, healthy Algerian parents. The proband was born by spontaneous vaginal delivery, at term. The pregnancy was uneventful. BW was $4100 \mathrm{~g}(+1.6 \mathrm{SD}), \mathrm{BL}$ and $\mathrm{OFC}$ at 1 month were respectively $57 \mathrm{~cm}(+1.3 \mathrm{SD})$ and $37 \mathrm{~cm}(+0.1 \mathrm{SD})$. Axial hypotonia was noted at 9 months. He sat alone at 12 months and walked at age $2 \frac{1}{2}$ years. Speech was severely delayed. At 30 months, his weight was $9800 \mathrm{~g}(-1.5 \mathrm{SD})$, length was $78 \mathrm{~cm}(-1.8 \mathrm{SD})$ and OFC was $46 \mathrm{~cm}$ (-1 SD). He had prominent forehead, short philtrum, downslanting corners of the mouth, micrognathia, low-set ears (Fig. 1 c, d), strabismus and syndactyly of the $2^{\text {nd }}$ and $3^{\text {rd }}$ toes. Cardiac USS showed mild aortic stenosis. During childhood, hypotonia regressed and growth retardation worsened (weight and length between -2 and -3 SD). Transfontanellar USS performed in infancy showed wide cisterna magna and possible cortical atrophy. He had asymmetric myopia (- $0.5 \mathrm{~d} /$ - 5 d). Fundus oculi documented large, hypopigmented papillae. Brain MRI or CT were not available. At age 7, his weight was $18.5 \mathrm{~kg}(-1.3 \mathrm{SD})$, his height $110 \mathrm{~cm}(-2$ SD) and his OFC $52 \mathrm{~cm}(-0.2 \mathrm{SD})$. He presented with a mild intellectual disability. His expressive level was estimated to be satisfactory for his age, but he was unable to write, read or follow mainstream schooling. 
El Khattabi et al., 6

\section{Patient 3}

This 15 year-old boy was the first child of non-consanguineous, healthy parents. He had two healthy brothers. Pregnancy, neonatal period and early developmental milestones were unremarkable. He was referred to the pediatric clinics for post-natal short stature at -3 SD. Endocrine work-up revealed growth hormone deficiency. He followed mainstream school but required speech therapy. He had long and thin philtrum and thin upper lip. He was short-sighted. Cryptorchidism was surgically cured in late infancy. At age 14 years 5 months, he was $136 \mathrm{~cm}$ tall (-2.7 SD), and weighted $35.9 \mathrm{~kg}(-1.1 \mathrm{SD})$. He had no signs of puberty (Tanner stages: A1P1G1). GH replacement was not satisfactory, despite normalized IGF1 levels, with a gain of only $2 \mathrm{~cm}$ in a 6-month period.

\section{Patient 4}

This patient was the second child of a non-consanguineous couple from Sri Lanka. Gestational diabetes required insulin treatment. He was born prematurely at $34 \mathrm{WG}$. BW was $2500 \mathrm{~g}$ (-1 SD), BL $47 \mathrm{~cm}$ (-1 SD), and OFC $32.5 \mathrm{~cm}$ (- $0.5 \mathrm{SD})$. Apgar score was 9/10. His psychomotor development was moderately delayed: he sat alone at 10 months, walked at 18 months and said his first words at 30 months. At 3 years of age, he was referred to the pediatric clinics for speech delay and abnormal skin pigmentation. His weight was $11.6 \mathrm{~kg}$ (-2 SD), length $88 \mathrm{~cm}(-2 \mathrm{SD})$ and OFC $48 \mathrm{~cm}(-1.5 \mathrm{SD})$. He was not dysmorphic but had occipital plagiocephaly and convergent strabismus (Fig. 1 e). He had a few large hypopigmented skin lines following Blaschko lines on the trunk and limb roots (Fig. 1 f, g). Ocular fundi, EEG, brain MRI, heart and kidney USS were normal.

\section{Patient 5}

This patient was the third child of healthy non consanguineous parents, born at 38 WG. Prenatal USS showed small OFC and large anterior fontanel. BW was $2900 \mathrm{~g}(-0.8 \mathrm{SD}), \mathrm{BL} 48 \mathrm{~cm}$ (-0.8 SD) and OFC $31.5 \mathrm{~cm}(-2.6 \mathrm{SD})$. She had failure to thrive and severe gastroesophageal reflux. She developed chronic ENT infections and furunculosis. Later, she developed several pilomatricomas. She walked unsupported at 18 months of age and had speech delay. She was raised in a normal school, but required speech and physical therapies. She nevertheless achieved reading and writing at age 6 yearold. She was first seen at 7.5 years of age. Growth was within the low normal range (weight on -2 SD, length on $-1 \mathrm{SD}$ and OFC on $-1.5 \mathrm{SD}$ ). She was not dysmorphic. She had hypopigmented Blaschko lines, widely spaced nipples, clinodactyly of the $5^{\text {th }}$ fingers, and bilateral 2-3 toes syndactyly.

\section{Patient 6}

This girl was the sixth child born to a 37.4 year-old mother and a 42 year-old father. The pregnancy was uneventful. BW was $3,730 \mathrm{~g}(+0.9 \mathrm{SD}), \mathrm{BL} 50 \mathrm{~cm}(+0.3 \mathrm{SD})$ and OFC $35.5(+1 \mathrm{SD})$. Apgar score was 10/10. Growth and weight followed the +1 SD curve. Psychomotor development was moderately delayed. She sat alone à 11 months and walked at 2 years. At age 3 years, her speech was extremely poor, with behavioral problems related to autism spectrum disorder. No dysmorphic signs were noted. Brain CT scan was normal, as well as kidney USS and X-ray skeletal survey.

\section{Patient 7}


El Khattabi et al., 7

This eighteen year-old female was born to healthy unrelated 32 year-old mother and 34 year-old father. Birth was at full term. BW was 2,690 g (-1.2 DS), BL $49 \mathrm{~cm}$ (-0.8 DS) and OFC $31 \mathrm{~cm} \mathrm{(-3.1}$ DS). During the first two years, she had severe gastro-esophageal reflux and chronic ENT infections. She walked at 18 months of age and speech was delayed. Her growth followed low normal curves (weight on -2 DS and height on -1 DS curves). Puberty started at 11 years of age. She followed mainstream school with the help of psychomotor and speech therapies. Her facial dysmorphism consisted in square shaped face, flat forehead, right ptosis, prominent nose root, thin mouth, micrognathia, overfolded helices, and crowded teeth. She had palmar erythrosis, dry skin and multiple pilomatricomas. She also presented Raynaud disease. She had had attention deficit and weaknesses in long term memory. No behavioral disorders were observed.

\section{Patient 8}

This 3 year-old girl is the unique child born to healthy non consanguineous 25 year-old mother and 28 year-old father after an uneventful pregnancy. Delivery was induced at $37 \mathrm{GW}$ for weight stagnation. BW was $2,700 \mathrm{~g}\left(<10^{\text {th }}\right.$ centile $)$, BL $45 \mathrm{~cm}\left(<3^{\text {th }}\right.$ centile $)$ and $\mathrm{OFC} 32 \mathrm{~cm}\left(10^{\text {th }}\right.$ centile $)$. She sat unsupported at 8 months of age and presented tiptoe walking since 20 months of age. Physical examination at 22 months revealed a pyramidal syndrome, microcephaly (-3 SD), bilateral single palmar creases and particular facial traits: narrow palpebral fissures, large forehead, short philtrum and nasal root hypoplasia (Fig. 1 h). Speech was delayed. At last examination (34 months), walking was normalized after plastering and reeducation, language was still poor and head circumference was at -2 SD. Cerebral MRI was normal.

\section{Patient 9}

This 20 months old female is the second child born to healthy unrelated parents. The pregnancy was uneventful. Birth was at full term. BW was $2780 \mathrm{~g}(-1.04 \mathrm{SD})$, BL $47 \mathrm{~cm}(-0.22 \mathrm{SD})$ and OFC $33 \mathrm{~cm}$ (-1.27 SD). Motor milestones were delayed. At 20 months, she sat intermittently. At 20 months, she could not stand unsupported and had no speech. She had low-set ears, epicanthal folds and hypertelorism. Cerebral MRI showed ventricle enlargement and small, bilateral temporal arachnoid cysts.

\section{Patient 10}

This male fetus was the product of the $2^{\text {nd }}$ pregnancy of healthy, unrelated parents. The mother was 33 -year-old at birth. First trimester USS revealed an increased nuchal translucency $\left(>97^{\text {th }}\right.$ centile), bilateral cleft lip and palate, mandibular hypoplasia, absence of the nasal bones and an abnormal position of the hands. Fetal size was normal. The pregnancy was terminated at $13 \mathrm{WG}$ after diagnosis of non-mosaic T9p on chorionic villi. Further post mortem examination showed low-set ears, hypospadias, single umbilical artery, and renal microcysts arising from the ducts (Fig. 1 i).

\section{Patient 11}

This male fetus was the product of the first pregnancy of healthy unrelated parents. The mother was 43 year-old at time of birth. Maternal serum screening indicated a high risk of trisomy $21(1 / 141)$. 
Amniocentesis disclosed mosaic T9p. Ultrasound examination at $22 \mathrm{WG}$ showed IUGR, abnormal facial profile, dedifferentiated cortico-medullar junction in kidneys, agenesis of the corpus callosum, mild ventriculomegaly and Dandy-Walker malformation. The pregnancy was terminated at 23 WG. Pathological examination showed IUGR (452 g, vertex heel $28 \mathrm{~cm}$, vertex coccyx $20 \mathrm{~cm}, \mathrm{HC} 19 \mathrm{~cm}$, all $<3^{\text {th }}$ centile), cleft lip and palate, dysplastic, low-set ears, micrognathia, short neck, bilateral single palmar creases, short and large thumbs, hypoplastic nails and rockerbottom feet (Fig. 1 j). Visceral anomalies included abnormal pulmonary lobation, single umbilical artery, common mesentery, asymmetry of the cardiac ventricles and large non lobated kidneys. Neuropathological examination confirmed the cerebral malformation: corpus callosum agenesis, partial vermian agenesis and enlargement of the $4^{\text {th }}$ ventricle (Fig. $1 \mathrm{k}, 1$ ).

\section{Patient 12}

This fetus was the sib of patient 11. He was found dead at the first ultrasound examination at 12 WG. A $4.1 \mathrm{~mm}$ nuchal edema was observed. Craniocaudal length was $59.2 \mathrm{~mm}$ ( $5^{\text {th }}$ centile). No pathological examination was performed.

\section{Methods}

Conventional cytogenetics and FISH. GTG-, RHG-and/or CBG-banding were performed on blood (patients 1-9), chorionic villi (patient 10), amniocytes (patients 10 and 11) and skin fibroblasts (patients 1, 3, 4, 7 and 8) according to standard cytogenetic procedures. Confirmation was performed by FISH using commercial probes. Interphase FISH using chromosome 9 centromeric probe were performed on urine centrifugate for patients 1 and 4, and on buccal epithelial cells for patients 6, 7 and 9.

Microarray studies. DNA was extracted using Qiagen kit (Qiagen, Valencia, CA, USA), from uncultured lymphocytes for patients 1-9, liver for patient 10, lung tissue for patient 11 and uncultured amniotic fluid (AF) cells for patient 12.

For patients 1, 2 and 4, whole genome CGH array was undertaken with a dye-swap technique using a 5.2 K BAC microarray (Perkin-Elmer, Waltham, MA, USA) following the Perkin Elmer protocol. The results were analyzed with SpectralWare Array Software. For patients 3, 5, 7-12, Agilent Human Genome CGH microarray 44K (patients 3, 9-12) or 60K (patients 5, 7 and 8) was used following standard manufacturer's recommendations (Agilent Technologies, Santa Clara, CA, USA). For reference DNA, an anonymous normal DNA was used for patients 3, 5 and 10, and a commercial genomic DNA for patients 11 and 12 (Promega, Madison, WI, USA). For patients 1, 2, 4, 7-9, DNA samples were labeled and hybridized in a dye-swap manner. Hybridization results were extracted with the Feature Extraction software and analyzed with the DNA-Analytics software. For patient 6, a SNP microarray analysis was performed using the Illumina HumanHap300 BeadChips platform (Illumina Inc., San Diego, CA, USA). Data was analyzed with the Genome Studio software. 
El Khattabi et al., 9

Probes positions were established for all cases using the Genome Browser Assembly hg19 (NCBI Build 37) (http://genome.ucsc.edu/cgi-bin/hgGateway ).

\section{RESULTS}

Results of conventional and molecular karyotyping are presented in Table 2.

\section{DISCUSSION}

Prevalence of supernumerary isochromosomes and isodicentric chromosomes ranges from 0.14 to 0.72 per 1000 live births [Rothlisberger et al., 2000]. The most commonly described are i(8p), i(9p), i(12p) or Pallister-Killian syndrome, i(18p) and i(22q) or cat-eye syndrome. Except for i(22q), phenotypic expression of these autosomal tetrasomies is often severe. Isochromosomes usually show a tissuerestricted mosaicism: $\mathrm{i}(8 \mathrm{p})$ is found almost only in lymphocytes, $\mathrm{i}(12 \mathrm{p})$ in fibroblasts, and $\mathrm{i}(9 \mathrm{p})$ in lymphocytes and at a lower level in fibroblasts (where it can be absent), as observed in our series.

Isochromosomes usually occur de novo, except for rare cases of tetrasomy 18p [Dutly et al., 1998]. Most markers are of maternal origin. A U-type exchange rearrangement has been suggested as the mechanism of formation following either a meiotic or mitotic non-disjunction, leading to duplication associated to deletion [Bugge et al., 1996; Dutly et al., 1998; Kotzot et al., 1996; Liehr et al., 2004]. Maternal age seems uncorrelated with the occurrence of this chromosomal aberration: mean maternal age in reported patients is 32.3 (Table 1). Recurrence, as observed for patients 11 and 12, has never been reported with i(9p). Gonadal mosaicism seems the more likely explanation for these sibs.

Most fetuses with T9p were detected because of the presence of MCA prompting for fetal karyotyping except one, fortuitously diagnosed following an amniocentesis for advanced maternal age [Eggermann et al., 1998]. In prenatally diagnosed cases, cerebral abnormalities, as ventriculomegaly and DandyWalker malformation $(60 \%)$ are the most frequent reported anomalies, followed by cleft lip/palate (55\%) and IUGR (45\%) [Cazorla Calleja et al., 2003; Chen et al., 2007; Chen et al., 2014; Coman et al., 2008; Deurloo et al., 2004; Dhandha et al., 2002; di Vera et al., 2008; Dutly et al., 1998; Eggermann et al., 1998; Grass et al., 1993; Hengstschlager et al., 2004; McDowall et al., 1989; Nakamura-Pereira et al., 2009; Park et al., 1995; Podolsky et al., 2011; Tan et al., 2007; Tang et al., 2004; Van Hove et al., 1994]. In our series, Dandy-Walker malformation was observed for patient 11, cleft lip/palate was noted in patients 10 and 11, and IUGR was present in patients 1,8 and 11. Patient 7 showed absent nasal bones at the first trimester USS. This anomaly was previously reported in only one T9p fetus [Podolsky et al., 2011].

At birth, facial dysmorphism is too subtle to suggest the diagnosis. Rarely, patients may present multiple congenital anomalies (MCA) syndrome. During childhood, growth and cognitive development show a wide variability and may be normal [Nakamura et al., 1990; Papoulidis et al., 2012]. Some patients showed unexpected phenotypes, such as isolated oligospermia [McAuliffe et al., 2005], a phenotype mimicking Klinefelter syndrome [Ogino et al., 2007; Peters et al., 1982]

The variability of clinical expression of $i(9 p)$ is illustrated by Table 1 . Interestingly, 3 patients of our series have pilomatricomas. These benign skin tumors have not been previously described in T9p, but 
they are known in trisomy 9p [Blaya et al., 2009]. Additionally, patient 1 displays abnormal enamel, which has not been reported before with $\mathrm{i}(9 \mathrm{p})$.

The phenotypic variability of T9p is largely unexplained. It has been suggested that the severity of the phenotype might be related to the degree of mosaicism [Grass et al., 1993; Schaefer et al., 1991; Van Hove et al., 1994] but most reports studied only one tissue. Little is known about the impact of tissuelimited mosaicism. Regardless to the level of mosaicism, phenotype of patients with $i(9 p)$ in fibroblasts tends to be more severe than those whose i $(9 p)$ is limited to lymphocytes, especially in terms of cardiac defects and viability (Table 3), although our patient 1 who has a mild phenotype despite $90 \%$ of supernumerary marker in blood and $30 \%$ in skin, is a counter-example. Cleft lip/palate was only reported when i $(9 p)$ was found elsewhere than in blood tissue.

The influence of breakpoints position (p10, q12, q13, q21 or q22) on the severity of phenotype is controversial [Dhandha et al., 2002; Grass et al., 1993; Stumm et al., 1999]. Based on 49 previous reports and our patients, involvement of 9q region appears to be more often associated with cardiac malformations, intellectual deficiency and death (Table 4). Surprisingly, this is true even when only $9 q$ pericentromeric heterochromatin is present. This could be due to the poor resolution of conventional cytogenetic techniques on which breakpoints mapping was based in previous reports, or to the small number of cases in each group making precise analysis hazardous. In the present series where the $i(9 p)$ or idic(9p) of all patients were characterized by microarray analysis, only one patient had an idic(9p) including 9q21 region, making impossible to study the correlation between clinical phenotype and $9 \mathrm{q}$ euchromatine region involvement.

Based on published reports, the prognosis of T9p is poor: 18/43 patients born alive died during the first year of life, among which 15 died before 3 months. All deceased patients had homogenous T9p in lymphocytes [Calvieri et al., 1988; Cavalcanti et al., 1987; de Azevedo Moreira et al., 2003; Dhandha et al., 2002; Ghymers et al., 1973; Henriques-Coelho et al., 2005; Jalal et al., 1991; Leichtman et al., 1996; Melaragno et al., 1992; Moedjono et al., 1980; Schaefer et al., 1991; Shapiro et al., 1985; Tang et al., 2004; Wisniewski et al., 1978] and/or amniotic fluid when T9p was diagnosed prenatally and pregnancy leads to birth [Dhandha et al., 2002; Nakamura-Pereira et al., 2009; Park et al., 1995; Tang et al., 2004]. Eight patients were tested for a distinct tissue and the marker was present in all cells for five of them [Calvieri et al., 1988; Ghymers et al., 1973; Jalal et al., 1991; Melaragno et al., 1992; Park et al., 1995; Schaefer et al., 1991; Tang et al., 2004]. Moreover, among alive patients for which the i(9p) was present homogeneously in lymphocytes [Cuoco et al., 1982; Dutly et al., 1998; GarciaCruz et al., 1982; Papoulidis et al., 2012; Peters et al., 1982; Shehab et al., 2011; Tonk 1997], only four patients have been investigated for a second tissue (skin or buccal smear): the marker was absent in two of them [Cuoco et al., 1982; Peters et al., 1982] and present in 65\% of buccal mucosa cells in one of them [Papoulidis et al., 2012] and in 85\% saliva cells in another one [Shehab et al., 2011]. Our liveborn patients are aged 3 to 19 years. The supernumerary marker is present in a mosaic state either in peripheral blood (patients 1, 2, 4-6 and 9) or in fibroblasts (patients 3, 8 and 9). These data support 
the poor prognosis of $\mathrm{T} 9 \mathrm{p}$ when the supernumerary marker is found homogeneously in two distinct tissues.

In this study, we show that the phenotype of T9p is highly variable. Patients with a low mosaicism level or a tissue limited mosaicism are likely to be misdiagnosed. For those ones, clinical examination could give diagnosis clues. Phenotypic variability could not be simply extrapolated from the position of the breakpoints because of lack of precise data in previous reports. Nevertheless, a trend to increased severity appears when $9 \mathrm{q}$ region is present and when at least two tissues are affected. In the light of this review, it would be interesting, for a better comprehension of this syndrome, to characterize precisely the breakpoints and to study at least two types of tissue.

Conflict of interest: The authors declare no conflict of interest.

Acknowledgements: We thank Dr Khantaby Pluquailec for cytogenetic studies.

\section{References}

Abe T, Morita M, Kawai K, Misawa S, Takino T, Hashimoto H, Nakagome Y. 1977. Partial tetrasomy 9(9pter to 9q2101) due to an extra iso-dicentric chromosome. Ann Genet 20(2):111-114.

Andou R, Mimaki T, Ogihara T, Tamai H, Mino M. 1994. A case of tetrasomy 9p. Acta Paediatr Jpn 36(6):724-726.

Balestrazzi P, Croci G, Frassi C, Franchi F, Giovannelli G. 1983. Tetrasomy 9p confirmed by GALT. J Med Genet 20(5):396-399.

Blaya B, Gonzalez-Hermosa R, Gardeazabal J, Diaz-Perez JL. 2009. Multiple pilomatricomas in association with trisomy 9. Pediatric dermatology 26(4):482-484.

Bugge M, Blennow E, Friedrich U, Petersen MB, Pedeutour F, Tsezou A, Orum A, Hermann S, Lyngbye T, Sarri C, Avramopoulos D, Kitsiou S, Lambert JC, Guzda M, Tommerup N, Brondum-Nielsen K. 1996. Tetrasomy 18p de novo: parental origin and different mechanisms of formation. Eur J Hum Genet 4(3):160-167.

Calvieri F, Tozzi C, Benincori C, De Merulis MV, Bellussi A, Genuardi M, Neri G. 1988. Partial tetrasomy 9 in an infant with clinical and radiological evidence of multiple joint dislocations. Eur J Pediatr 147(6):645-648.

Cavalcanti DP, Ferrari I, de Almeida JC, de Pina Neto JM, de Oliveira JA. 1987. Tetrasomy 9p caused by idic (9) (pter----q13----pter). Am J Med Genet 27(3):497-503.

Cazorla Calleja MR, Verdu A, Felix V. 2003. Dandy-Walker malformation in an infant with tetrasomy 9p. Brain Dev 25(3):220-223.

Chen CP, Chang TY, Chern SR, Lee CC, Town DD, Lee MS, Wang W. 2007. Prenatal diagnosis of low-level mosaic tetrasomy 9p by amniocentesis. Prenat Diagn 27(4):383-385.

Chen CP, Lin SP, Su JW, Lee MS, Wang W. 2012. Phenotypic features associated with mosaic tetrasomy $9 \mathrm{p}$ in a 20 -year-old female patient include autism spectrum disorder. Genet Couns 23(2):335-338. 
Chen CP, Wang LK, Chern SR, Wu PS, Chen YT, Kuo YL, Chen WL, Lee MS, Wang W. 2014. Mosaic tetrasomy $9 \mathrm{p}$ at amniocentesis: prenatal diagnosis, molecular cytogenetic characterization, and literature review. Taiwanese journal of obstetrics \& gynecology 53(1):79-85.

Coman D, Bacic S, Boys A, Sparrow DB, Dunwoodie SL, Savarirayan R, Amor DJ. 2008. Spondylocostal dysostosis in a pregnancy complicated by confined placental mosaicism for tetrasomy 9p. Am J Med Genet A 146A(15):1972-1976.

Cuoco C, Gimelli G, Pasquali F, Poloni L, Zuffardi O, Alicata P, Battaglino G, Bernardi F, Cerone R, Cotellessa M, Ghidoni A, Motta S. 1982. Duplication of the short arm of chromosome 9. Analysis of five cases. Hum Genet 61(1):3-7.

de Azevedo Moreira LM, Freitas LM, Gusmao FA, Riegel M. 2003. New case of non-mosaic tetrasomy 9p in a severely polymalformed newborn girl. Birth Defects Res A Clin Mol Teratol 67(12):985-988.

Deurloo KL, Cobben JM, Heins YM, de Ru M, Wijnaendts LC, van Vugt JM. 2004. Prenatal diagnosis of tetrasomy $9 \mathrm{p}$ in a 19-week-old fetus with Dandy-Walker malformation: a case report. Prenat Diagn 24(10):796-798.

Dhandha S, Hogge WA, Surti U, McPherson E. 2002. Three cases of tetrasomy 9p. Am J Med Genet 113(4):375-380.

di Vera E, Liberati M, Celentano C, Calabrese G, Guanciali-Franchi PE, Morizio E, Rotmensch S. 2008. Rhombencephalosynapsis in a severely polymalformed fetus with non-mosaic tetrasomy 9p, in intracytoplasmic-sperm-injection pregnancy. J Assist Reprod Genet 25(11-12):577-580.

Dutly F, Balmer D, Baumer A, Binkert F, Schinzel A. 1998. Isochromosomes 12p and 9p: parental origin and possible mechanisms of formation. Eur J Hum Genet 6(2):140-144.

Eggermann T, Rossier E, Theurer-Mainka U, Backsch C, Klein-Vogler U, Enders H, Kaiser P. 1998. New case of mosaic tetrasomy $9 \mathrm{p}$ with additional neurometabolic findings. Am J Med Genet 75(5):530-533.

Garcia-Cruz D, Vaca G, Ibarra B, Sanchez-Corona J, Ocampo-Campos R, Peregrina S, Moller M, Rivera H, Rivas F, Gonzalez-Angulo A, Cantu JM. 1982. Tetrasomy 9p: clinical aspects and enzymatic gene dosage expression. Ann Genet 25(4):237-242.

Ghymers D, Hermann B, Disteche C, Frederic J. 1973. [Partial tetrasomy of number 9 chromosome, and mosaicism in a child with multiple malformations (author's transl)]. Humangenetik 20(3):273-282.

Grass FS, Parke JC, Jr., Kirkman HN, Christensen V, Roddey OF, Wade RV, Knutson C, Spence JE. 1993. Tetrasomy 9p: tissue-limited $\operatorname{idic}(9 \mathrm{p})$ in a child with mild manifestations and a normal CVS result. Report and review. Am J Med Genet 47(6):812-816.

Hengstschlager M, Bettelheim D, Drahonsky R, Repa C, Deutinger J, Bernaschek G. 2004. Prenatal diagnosis of tetrasomy 9p with Dandy-Walker malformation. Prenat Diagn 24(8):623-626. 
El Khattabi et al., 13

Henriques-Coelho T, Oliva-Teles N, Fonseca-Silva ML, Tibboel D, Guimaraes H, Correia-Pinto J. 2005. Congenital diaphragmatic hernia in a patient with tetrasomy 9p. Journal of pediatric surgery 40(10):e29-31.

Jalal SM, Kukolich MK, Garcia M, Benjamin TR, Day DW. 1991. Tetrasomy 9p: an emerging syndrome. Clin Genet 39(1):60-64.

Kotzot D, Bundscherer G, Bernasconi F, Brecevic L, Lurie IW, Basaran S, Baccicchetti C, Holler A, Castellan C, Braun-Quentin C, Pfeiffer RA, Schinzel A. 1996. Isochromosome 18p results from maternal meiosis II nondisjunction. Eur J Hum Genet 4(3):168-174.

Leichtman LG, Zackowski JL, Storto PD, Newlin A. 1996. Non-mosaic tetrasomy 9p in a liveborn infant with multiple congenital anomalies: case report and comparison with trisomy 9p. Am J Med Genet 63(3):434-437.

Liehr T, Claussen U, Starke H. 2004. Small supernumerary marker chromosomes (sSMC) in humans. Cytogenet Genome Res 107(1-2):55-67.

Lloveras E, Perez C, Sole F, Zamora L, Lladonosa A, Espinet B, Silvestre E, Serra J, Vendrell T, Fernandez B, Salido M, Plaja A. 2004. Two cases of tetrasomy 9p syndrome with tissue limited mosaicism. Am J Med Genet A 124A(4):402-406.

McAuliffe F, Winsor EJ, Chitayat D. 2005. Tetrasomy 9p mosaicism associated with a normal phenotype. Fetal Diagn Ther 20(3):219-222.

McDowall AA, Blunt S, Berry AC, Fensom AH. 1989. Prenatal diagnosis of a case of tetrasomy 9p. Prenat Diagn 9(11):809-811.

Melaragno MI, Brunoni D, Patricio FR, Corbani M, Mustacchi Z, dos Santos Rde C, Lederman HM. 1992. A patient with tetrasomy 9p, Dandy-Walker cyst and Hirschsprung disease. Ann Genet 35(2):79-84.

Moedjono SJ, Crandall BF, Sparkes RS. 1980. Tetrasomy 9p: confirmation by enzyme analysis. J Med Genet 17(3):227-230.

Nakamura-Pereira M, Cima LC, Llerena JC, Jr., Guerra FA, Peixoto-Filho FM. 2009. Sonographic findings in a case of tetrasomy $9 \mathrm{p}$ associated with increased nuchal translucency and DandyWalker malformation. J Clin Ultrasound 37(8):471-474.

Nakamura Y, Sato E, Sakai K, Sakuma S, Hashimoto T, Sindou S. 1990. Abnormal chromosome 9 in a neonate program. Report of three cases. Arch Pathol Lab Med 114(2):185-187.

Ogino W, Takeshima Y, Nishiyama A, Yagi M, Oka N, Matsuo M. 2007. Mosaic tetrasomy 9p case with the phenotype mimicking Klinefelter syndrome and hyporesponse of gonadotropinstimulated testosterone production. Kobe J Med Sci 53(4):143-150.

Orye E, Verhaaren H, Van den Bogaert-Van Heesvelde AM. 1975. The 9p- deletion syndrome. Report of a patient with a $46, \mathrm{XX}, 9 \mathrm{P}$ - constitution due to a paternal $\mathrm{t}(9 \mathrm{p}-; 15+)$ translocation. Clin Genet 8(5):349-357. 


\section{Page 15 of 20}

El Khattabi et al., 14

Papenhausen P, Riscile G, Miller K, Kousseff B, Tedesco T. 1990. Tissue limited mosaicism in a patient with tetrasomy 9p. Am J Med Genet 37(3):388-391.

Papoulidis I, Kontodiou M, Tzimina M, Saitis I, Hamid AB, Klein E, Kosyakova N, Kordass U, Kunz J, Siomou E, Nicolaides P, Orru S, Thomaidis L, Liehr T, Petersen MB, Manolakos E. 2012. Tetrasomy $9 \mathrm{p}$ mosaicism associated with a normal phenotype in two cases. Cytogenet Genome Res 136(4):237-241.

Park JP, Rawnsley BE, Marin-Padilla M. 1995. Tetrasomy 9p syndrome. Ann Genet 38(1):54-56.

Peters J, Pehl C, Miller K, Sandlin CJ. 1982. Case report of mosaic partial tetrasomy 9 mimicking Klinefelter syndrome. Birth Defects Orig Artic Ser 18(3B):287-293.

Podolsky R, Saltzman D, Auerbach M, Roman AS. 2011. Absent nasal bone as a marker of tetrasomy 9p. Prenat Diagn 31(13):1313.

Rothlisberger B, Chrzanowska K, Balmer D, Riegel M, Schinzel A. 2000. A supernumerary marker chromosome originating from two different regions of chromosome 18. J Med Genet $37(2): 121-124$.

Rutten FJ, Scheres JM, Hustinx TW, ter Haar BG. 1974. A presumptive tetrasomy for the short arm of chromosome 9. Humangenetik 25(3):163-170.

Schaefer GB, Domek DB, Morgan MA, Muneer RS, Johnson SF. 1991. Tetrasomy of the short arm of chromosome 9: prenatal diagnosis and further delineation of the phenotype. Am J Med Genet 38(4):612-615.

Shapiro SD, Hansen KL, Littlefield CA. 1985. Brief clinical report: non-mosaic partial tetrasomy and partial trisomy 9. Am J Med Genet 20(2):271-276.

Shehab MI, Mazen I, Bint S. 2011. Tissue-specific mosaicism for tetrasomy $9 \mathrm{p}$ uncovered by array CGH. Am J Med Genet A 155A(10):2496-2500.

Stumm M, Tonnies H, Mandon U, Gotze A, Krebs P, Wieacker PF. 1999. Mosaic tetrasomy 9p in a girl with multiple congenital anomalies: cytogenetic and molecular-cytogenetic studies. Eur J Pediatr 158(7):571-575.

Tan YQ, Chen XM, Hu L, Guan XY, Lu GX. 2007. Prenatal diagnosis of nonmosaic tetrasomy 9p by microdissection and FISH: case report. Chin Med J (Engl) 120(14):1281-1283.

Tang W, Boyd BK, Hummel M, Wenger SL. 2004. Prenatal diagnosis of tetrasomy 9p. Am J Med Genet A 126A(3):328.

Tonk VS. 1997. Moving towards a syndrome: a review of 20 cases and a new case of non-mosaic tetrasomy 9p with long-term survival. Clin Genet 52(1):23-29.

Van Hove J, Kleczkowska A, De Bruyn M, Bekaert J, Fryns JP. 1994. Tetrasomy 9p: prenatal diagnosis and fetopathological findings in a second trimester male fetus. Ann Genet 37(3):139-142.

Wisniewski L, Politis GD, Higgins JV. 1978. Partial tetrasomy 9 in a liveborn infant. Clin Genet 14(3):147-153. 
El Khattabi et al., 15

\section{Titles and Legends to figures}

Figure 1. Patients clinical features

Patient 1: (a) Facial appearance showing in particular a thin nose, short philtrum and low-set ears, (b) Pilomatricoma (benin subcutaneous tumor) in the neck. - Patient 2: (c) Face and (d) Profile views. Note the presence of a prominent forehead, short philtrum, downslanting corners of the mouth, micrognathia and low-set ears - Patient 4: (e) Facial appearance showing no particular dysmorphic features except occipital plagiocephaly and convergent strabismus, (f \& g) Blaschko lines on the trunk and limb roots - Patient 8: (h) Face view showing large forehead, short philtrum and nasal root hypoplasia - Patient 9: (i) Face view. Note low-set ears, epicanthal folds and hypertelorism - Patient 10 (13 WG fetus): (j) facial appearance: bilateral cleft lip and palate, mandibular hypoplasia and lowset ears - Patient 11 (23 WG fetus): (k) General appearance at necropsy showing cleft lip and palate, dysplastic and low-set ears, micrognathia, short neck, and rockerbottom feet, (1) Brain showing corpus callosum agenesis, (m) Cerebellum showing a partial vermian agenesis and enlargement of the $4^{\text {th }}$ ventricle. 


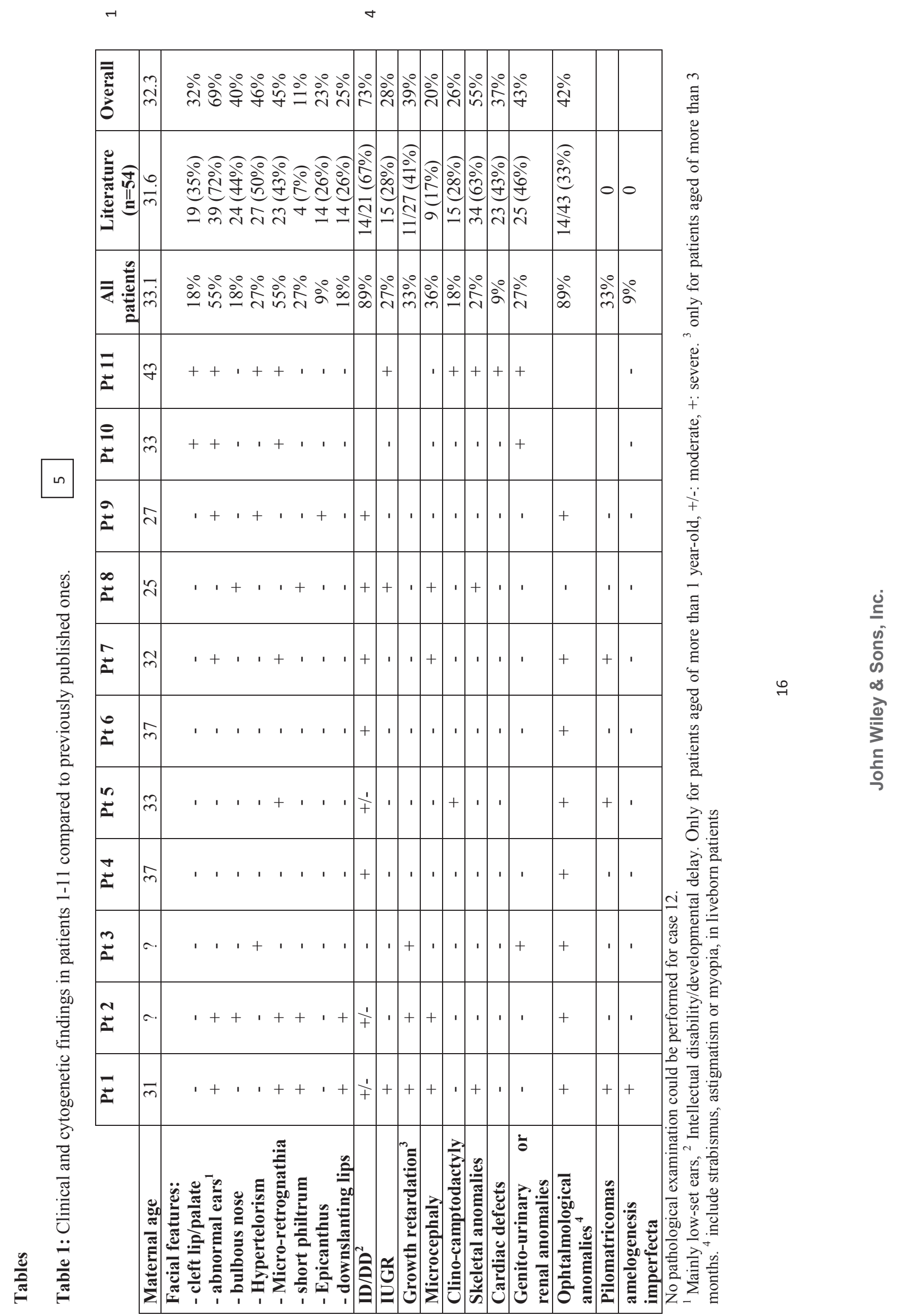

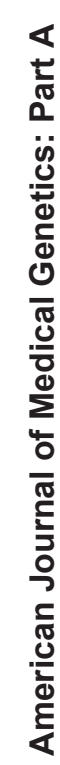


Table 2: Results of cytogenetic investigations.

\begin{tabular}{|c|c|c|c|c|}
\hline $\mathbf{P t}$ & $\begin{array}{c}\text { Karyotype for } \\
\text { abnormal cells } \\
\text { following conventional } \\
\text { cyogenetics }\end{array}$ & $\begin{array}{c}\text { Proportion of aneusomic } \\
\text { cells }\end{array}$ & $\begin{array}{l}\text { ISCN description of array } \\
\text { results (tissue assayed) }\end{array}$ & Remark \\
\hline 1 & $\begin{array}{l}47, X X,+ \text { psu } \\
\operatorname{idic}(9)(\text { pter } \rightarrow \text { q } 21:: q 21 \\
\rightarrow \text { pter })\end{array}$ & $\begin{array}{l}\text { Cultured lymphocytes: } 90 \% \\
\text { Cultured fibroblasts: } 30 \% \\
\text { Urine sediment: } 30 \%\end{array}$ & $\begin{array}{l}\operatorname{arr}[\text { hg19] 9p24.3q21.12 (1- } \\
73,100,000) \times 2 \sim 4 \text { (blood) }\end{array}$ & $\begin{array}{l}\text { Parents: } \\
\text { normal } \\
\text { karyotype }\end{array}$ \\
\hline 2 & $\begin{array}{l}47, X Y,+ \text { psu } \\
\operatorname{idic}(9)(\text { pter } \rightarrow \text { q12::q12 } \\
\rightarrow \text { pter) }\end{array}$ & Cultured lymphocytes: $60 \%$ & $\begin{array}{l}\operatorname{arr}[\mathrm{hg} 19] \text { 9p24.3q12 (1- } \\
60,300,000) \times 2 \sim 4 \text { (blood) }\end{array}$ & $\begin{array}{l}\text { Parents not } \\
\text { tested }\end{array}$ \\
\hline 3 & $47, \mathrm{XY},+\mathrm{i}(9)(\mathrm{p} 10)$ & $\begin{array}{l}\text { Cultured lymphocytes: } 100 \% \\
\text { Skin fibroblasts: } 30 \%\end{array}$ & $\begin{array}{l}\text { arr[hg19] } \\
9 \mathrm{p} 24.3 \mathrm{q} 11(214,367- \\
39,816,368) \times 4 \text { (blood) }\end{array}$ & $\begin{array}{l}\text { Parents not } \\
\text { tested }\end{array}$ \\
\hline 4 & $\begin{array}{l}47, X Y,+ \text { psu } \\
\operatorname{idic}(9)(\text { pter } \rightarrow \text { q12 or } \\
13:: q 13 \text { or } 12 \rightarrow \text { pter })\end{array}$ & $\begin{array}{l}\text { Cultured lymphocytes: } 60 \% \\
\text { Skin (colored) culture : } 6 \% \\
\text { Skin (pale) culture: } 10 \% \\
\text { Urine sediment: } 40 \%\end{array}$ & $\begin{array}{l}\operatorname{arr}[\text { hg19] 9p24.3q12 (1- } \\
60,300,000) \times 2 \sim 4 \text { (blood) }\end{array}$ & $\begin{array}{l}\text { Parents: } \\
\text { normal } \\
\text { karyotype }\end{array}$ \\
\hline 5 & $\begin{array}{l}47, X Y,+ \text { psu } \\
\operatorname{idic}(9)(\text { pter } \rightarrow \text { q12 or } \\
13:: q 13 \text { or } 12 \rightarrow \text { pter })\end{array}$ & Cultured lymphocytes: 90\% & $\begin{array}{l}\operatorname{arr}[\text { hg19] 9p24.3q11 } \\
(271,197-39,157,014) \times 2 \sim 4 \\
\text { (blood) }\end{array}$ & $\begin{array}{l}\text { Parents: } \\
\text { normal } \\
\text { karyotype }\end{array}$ \\
\hline 6 & $47, X Y,+i(9)(p 10)$ & $\begin{array}{l}\text { Cultured lymphocytes: } 90 \% \\
\text { Buccal smear: } 66 \%\end{array}$ & $\begin{array}{l}\operatorname{arr}[\text { hg19] 9p24.3q11 } \\
(36,587-42,364,007) \times 2 \sim 4 \\
\text { (blood) }\end{array}$ & $\begin{array}{l}\text { Parents: } \\
\text { normal } \\
\text { karyotype }\end{array}$ \\
\hline 7 & $\begin{array}{l}47, X Y,+ \text { psu } \\
\operatorname{idic}(9)(\text { pter } \rightarrow \text { q12 or } \\
13:: q 13 \text { or } 12 \rightarrow \text { pter })\end{array}$ & $\begin{array}{l}\text { Cultured lymphocytes: } 75 \% \\
\text { Skin fibroblasts: } 0 \% \\
\text { Buccal smear: } 40 \%\end{array}$ & $\begin{array}{l}\operatorname{arr}[\text { hg19] 9p24.3q11 } \\
(271,197-39,157,014) \times 2 \sim 4 \\
\text { (blood) }\end{array}$ & $\begin{array}{l}\text { Parents: } \\
\text { normal } \\
\text { karyotype }\end{array}$ \\
\hline 8 & $\begin{array}{l}47, X Y,+ \text { psu } \\
\operatorname{idic}(9)(\text { pter } \rightarrow \text { q13::q13 } \\
\rightarrow \text { pter) }\end{array}$ & $\begin{array}{l}\text { Cultured lymphocytes: } 50 \% \\
\text { Skin fibroblasts: } 2 / 50\end{array}$ & $\begin{array}{l}\operatorname{arr}[\text { hg19] 9p24.3q11 } \\
(204,193 \text { à } \\
45,469,390) \times 2 \sim 4 \text { (blood) }\end{array}$ & $\begin{array}{l}\text { Parents: } \\
\text { normal } \\
\text { karyotype }\end{array}$ \\
\hline 9 & $\begin{array}{l}47, X X,+ \text { psu } \\
\operatorname{idic}(9)(\text { pter } \rightarrow \mathrm{q} 12 \text { or } \\
13:: 13 \text { or } \mathrm{q} 12 \rightarrow \text { pter })\end{array}$ & $\begin{array}{l}\text { Cultured lymphocytes: } 80 \% \\
\text { Buccal smear: } 5 \%\end{array}$ & $\begin{array}{l}\text { arr[hg19] } \\
9 \mathrm{p} 24.3 \mathrm{q} 11(214,367- \\
39,816,368) \times 2 \sim 4 \text { (blood) }\end{array}$ & $\begin{array}{l}\text { Parents: } \\
\text { normal } \\
\text { karyotype }\end{array}$ \\
\hline 10 & $\begin{array}{l}47, X Y,+ \text { psu } \\
\operatorname{idic}(9)(\text { pter } \rightarrow \text { q12 or } \\
13:: 13 \text { or q12 } \rightarrow \text { pter })\end{array}$ & $\begin{array}{l}\text { CVS: } 100 \% \\
\text { Amniotic fluid: } 100 \%\end{array}$ & $\begin{array}{l}\text { arr[hg19] } \\
9 \mathrm{p} 24.3 \mathrm{q} 11(214,367- \\
39,816,368) \times 4 \text { (fetal liver) }\end{array}$ & $\begin{array}{l}\text { Parents: } \\
\text { normal } \\
\text { karyotype }\end{array}$ \\
\hline 11 & $47, \mathrm{XY},+\mathrm{i}(9)(\mathrm{p} 10)$ & Amniotic fluid: $72 \%$ & $\begin{array}{l}\operatorname{arr}[\mathrm{hg} 19] \\
9 \mathrm{p} 24.3 \mathrm{q} 11(214,367- \\
39,816,368) \times 2 \sim 4 \text { (fetal } \\
\text { lung) }\end{array}$ & $\begin{array}{l}\text { Parents: } \\
\text { normal } \\
\text { karyotype }\end{array}$ \\
\hline 12 & Failed & $\begin{array}{l}\text { Likely homogeneous, as the } \\
\text { array } \log 2 \text { ratio mean of the } \\
\text { duplicated region was } 0.96\end{array}$ & $\begin{array}{l}\operatorname{arr}[\text { hg19] } \\
\text { 9p24.3q11(214,367- } \\
39,816,368) \times 4 \text { (fresh } \\
\text { amniotic fluid) }\end{array}$ & $\begin{array}{l}\text { Sib of } \\
\text { patient } 11\end{array}$ \\
\hline
\end{tabular}


El Khattabi et al., 18

1

2

3

4

5

6

7

8

9

Table 3: Comparative clinical data between patients with detectable i(9p) in fibroblasts and those with i(9p) limited to lymphocytes

\begin{tabular}{|c|c|c|}
\hline & $\begin{array}{l}i(9 p) \text { present in a } \\
2^{\text {nd }} \text { tissue }(n=19)^{1}\end{array}$ & $\begin{array}{l}i(9 p) \text { not found in } \\
\text { a } 2^{\text {nd }} \text { tissue }(n=8)^{2}\end{array}$ \\
\hline $\begin{array}{l}\text { Facial features: } \\
\text { - cleft lip/palate } \\
\text { - abnormal ears } \\
\text { - bulbous nose } \\
\text { - Hypertelorism } \\
\text { - Micro-retrognathia } \\
\text { - Epicanthus } \\
\text { - downslanting lips }\end{array}$ & $\begin{array}{c}6(32 \%) \\
12(63 \%) \\
8(42 \%) \\
9(47 \%) \\
7(37 \%) \\
5(26 \%) \\
3(16 \%)\end{array}$ & $\begin{array}{c}0 \\
5(63 \%) \\
4(50 \%) \\
1(13 \%) \\
5(63 \%) \\
1(13 \%) \\
1(13 \%)\end{array}$ \\
\hline ID/DD ${ }^{4}$ & $5 / 10$ & $4 / 6$ \\
\hline IUGR & $8(42 \%)$ & $2(25 \%)$ \\
\hline Growth retardation ${ }^{5}$ & $4 / 13(31 \%)$ & $2 / 8(25 \%)$ \\
\hline Microcephaly & $4(21 \%)$ & $1(13 \%)$ \\
\hline Clino-camptodactyly & $3(16 \%)$ & $3(38 \%)$ \\
\hline Skeletal anomalies & $11(58 \%)$ & $5(63 \%)$ \\
\hline Cardiac defects & $6(32 \%)$ & $1(13 \%)$ \\
\hline $\begin{array}{l}\text { Genito-urinary or renal } \\
\text { anomalies }\end{array}$ & $9(47 \%)$ & $3(38 \%)$ \\
\hline Ophtalmological anomalies $^{6}$ & $8 / 18(44 \%)$ & $3(38 \%)$ \\
\hline Death & $6 / 18(33 \%)$ & $2(25 \%)$ \\
\hline
\end{tabular}

${ }^{1}$ Patients 1, 3, 4, 6, 8 and 9 and reported ones [Calvieri et al., 1988; Chen et al., 2014; Dhandha et al., 2002; Jalal et al., 1991; Lloveras et al., 2004; Ogino et al., 2007; Orye et al., 1975; Papenhausen et al., 1990; Papoulidis et al., 2012; Park et al., 1995; Schaefer et al., 1991; Shehab et al., 2011; Tang et al., 2004].

${ }^{2}$ Patient 7 and reported ones [Coman et al., 2008; Cuoco et al., 1982; Ghymers et al., 1973; Grass et al., 1993; Lloveras et al., 2004; Melaragno et al., 1992; Peters et al., 1982].

${ }^{3}$ Mainly low-set ears, ${ }^{4}$ Intellectual disability/developmental delay. Only for patients aged of more than 1 yearold, +/-: moderate, + : severe. ${ }^{5}$ only for patients aged of more than 3 months. ${ }^{6}$ include strabismus, astigmatism or myopia in liveborn patients 
Table 4: Malformations and risk of early death in relation with breakpoints.

\begin{tabular}{|l|c|c|c|}
\hline Breakpoint & p10 (n=21) & $\begin{array}{c}\text { q12 or q13 } \\
(\mathbf{n}=\mathbf{2 9})^{\mathbf{2}}\end{array}$ & $\begin{array}{c}\text { q21 or q22 } \\
(\mathbf{n}=\mathbf{1 0})^{\mathbf{3}}\end{array}$ \\
\hline Cardiac defects & $7(33 \%)$ & $12(41 \%)$ & $4(40 \%)$ \\
\hline Cerebral defects & $10(48 \%)$ & $14(48 \%)$ & $3(30 \%)$ \\
\hline ID/DD & $4 / 9$ & $12 / 13$ & $3 / 3$ \\
\hline Death & $7 / 19(37 \%)$ & $9 / 24(38 \%)$ & $4 / 8(50 \%)$ \\
\hline
\end{tabular}

Patient 3, 6 and 11, and previously reported ones [de Azevedo Moreira et al., 2003; Eggermann et al., 1998; Garcia-Cruz et al., 1982; Henriques-Coelho et al., 2005; Leichtman et al., 1996; Lloveras et al., 2004; McAuliffe et al., 2005; McDowall et al., 1989; Moedjono et al., 1980; Nakamura-Pereira et al., 2009; Ogino et al., 2007; Orye et al., 1975; Papoulidis et al., 2012; Rutten et al., 1974; Schaefer et al., 1991; Shehab et al., 2011; Tang et al., 2004].

${ }^{2}$ Patients 2, 4, 5, 7, 8, 9 and 10, and reported ones [Balestrazzi et al., 1983; Cavalcanti et al., 1987; Cazorla Calleja et al., 2003; Chen et al., 2007; Chen et al., 2012; Deurloo et al., 2004; Dhandha et al., 2002; di Vera et al., 2008; Dutly et al., 1998; Ghymers et al., 1973; Grass et al., 1993; Hengstschlager et al., 2004; Jalal et al., 1991; Lloveras et al., 2004; Melaragno et al., 1992; Papenhausen et al., 1990; Park et al., 1995; Peters et al., 1982; Stumm et al., 1999; Tonk 1997; Van Hove et al., 1994].

${ }^{3}$ Patient 1 and previous reports [Abe et al., 1977; Andou et al., 1994; Calvieri et al., 1988; Chen et al., 2014; Dhandha et al., 2002; Nakamura et al., 1990; Shapiro et al., 1985; Tan et al., 2007; Wisniewski et al., 1978].

${ }^{4}$ Intellectual disability/developmental delay 


\section{Page 21 of 20}
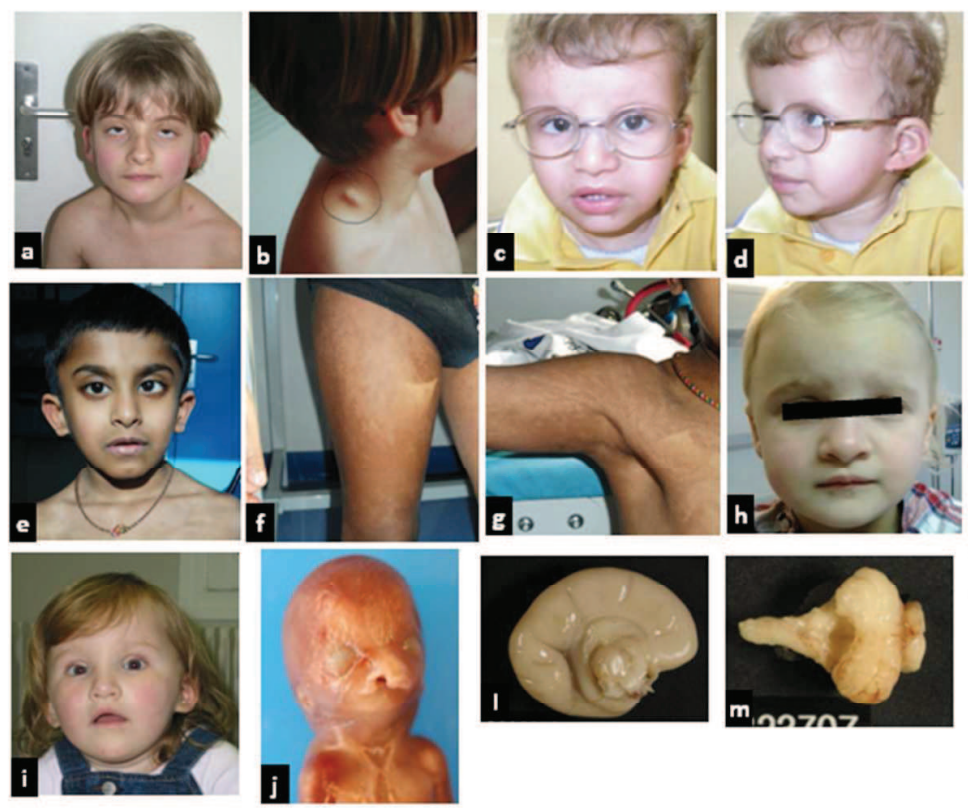

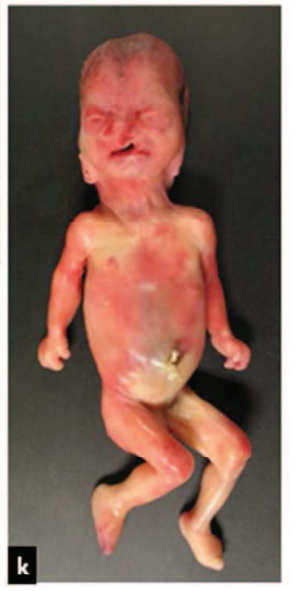

Patients clinical features

Patient 1: (a) Facial appearance showing in particular a thin nose, short philtrum and low-set ears, (b) Pilomatricoma (benin subcutaneous tumor) in the neck. - Patient 2: (c) Face and (d) Profile views. Note the presence of a prominent forehead, short philtrum, downslanting corners of the mouth, micrognathia and low-set ears - Patient 4: (e) Facial appearance showing no particular dysmorphic features except occipital plagiocephaly and convergent strabismus, ( $f$ \& g) Blaschko lines on the trunk and limb roots - Patient 8: (h) Face view showing large forehead, short philtrum and nasal root hypoplasia - Patient 9: (i) Face view. Note low-set ears, epicanthal folds and hypertelorism - Patient 10 (13 WG fetus): (j) facial appearance: bilateral cleft lip and palate, mandibular hypoplasia and low-set ears - Patient 11 (23 WG fetus): (k) General appearance at necropsy showing cleft lip and palate, dysplastic and low-set ears, micrognathia, short neck, and rockerbottom feet, (I) Brain showing corpus callosum agenesis, (m) Cerebellum showing a partial vermian agenesis and enlargement of the 4th ventricle. $200 \times 129 \mathrm{~mm}(96 \times 96 \mathrm{DPI})$ 